DOI: https://doi.org/10.15407/techned2019.06.025

\title{
OPTIMIZATION OF INDUCTIVE-CAPACITAL CONVERTER WITH BRIDGE ONE-PHASE RECTIFIER, CAPACITARY FILTER AND PARALLEL ACTIVE LOAD
}

Journal

Publisher

ISSN

Issue

Pages
Tekhnichna elektrodynamika

Institute of Electrodynamics National Academy of Science of Ukraine 1607-7970 (print), 2218-1903 (online)

No 6, 2019 (November/December)

$25-29$

\section{Authors}

V.M. Spirin ${ }^{\star}$, V.M. Hubarevich*, Yu.V. Maruniaa**, S.V. Salko, V.G. Grebenyuk Institute of Electrodynamics, National Academy of Sciences of Ukraine, pr. Peremohy, 56, Kyiv, 03057, Ukraine, e-mail: sspirin@ied.org.ua

* ORCID ID : http://orcid.org/0000-0002-8065-1051

** ORCID ID : http://orcid.org/0000-0003-2416-9858

*** ORCID ID : http://orcid.org/0000-0003-0071-1702

\section{Abstract}

The optimization of the specific capacities of the reactive elements of the inductive-capacitive converter according to the scheme G1-LC, which feeds a single-phase bridge rectifier with a capacitive filter and active load, is carried out. The optimization was done according to the theory of planning the experiments on the second order orthogonal plan. The obtained results allow us to calculate the parameters of the reactive elements of the ICC, which have a minimum specific capacities. References 4, figures 5, table 1.

Key words: rectifier, inductive-capacitive converter, specific capacities, reactive elements, active load, capacitive. 
Accepted: 16.09 .2019

Published: 25.10.2019

\section{References}

1. Spirin V.M., Gubarevich V.M., Salko S.V., Marunia Yu.V., Grebenyuk V.G. Determination of the coefficient of conversion of the bridge of single-phase rectifier with power from the inductive capacitor converter and parallel active capacity load. Tekhnichna Elektrodynamika. 2019. No 5. Pp. 43-48. (Ukr) DOI:

https://doi.org/10.15407/techned2019.05.043

2. Milyakh A.N., Volkov I.V. Systems of constant current which based on inductive-capacitive converters. Kiev: Naukova Dumka, 1974. 216 p. (Rus)

3. Pinchuk S.I. Organization of the experiment in modeling and optimization of technical systems. Dnepropetrovsk: LLC Independent Publishing Organization Diva, 2008. 248 p. (Rus) 4. Yudin Yu.V., Maysuradze M.V., Vodolazsky F.V. Organization and mathematical planning of the experiment. Ekaterinburg: Publishing House Ural. University, 2018. 124 p. (Rus) 